\title{
Namibia and the United Nations: A Turning Point in the Understanding of National Sovereignty
}

\author{
Xiaofan Han'1, John Klinger ${ }^{2}$, Patrick Snabes ${ }^{3}$, Alice Li ${ }^{4}$ \\ ${ }^{1}$ Wuhan Foreign Languages School, Wuhan, China \\ ${ }^{2}$ St. Albans School, Washington DC, USA \\ ${ }^{3}$ Greenhills School, Ann Arbor, USA \\ ${ }^{4}$ Beijing World Youth Academy, Beijing, China \\ Email: hanxiaofan2017@yahoo.com
}

How to cite this paper: Han, X. F., Klinger, J., Snabes, P., \& Li, A. (2016). Namibia and the United Nations: A Turning Point in the Understanding of National Sovereignty. Open Journal of Political Science, 6, 466474.

http://dx.doi.org/10.4236/ojps.2016.64039

Received: September 30, 2016

Accepted: October 25, 2016

Published: October 28, 2016

Copyright $\odot 2016$ by authors and Scientific Research Publishing Inc. This work is licensed under the Creative Commons Attribution International License (CC BY 4.0).

http://creativecommons.org/licenses/by/4.0/

\begin{abstract}
This paper tries to answer the question that "To what extent did the UN policy in South West Africa represent a successful and legitimate change in attitude and action by the United Nations towards the sovereignty of individual states when compared to indigenous peoples' right to self-determination?" This paper analyzes to what extent UN involvement in the colony of South West Africa, now known as Namibia, constituted a tangible change in UN, and therefore globally held, views on national sovereignty. Namibia itself has a long and complicated history. The United Nations' response to the colonization of South West Africa represented a fundamental change in the traditional view of sovereignty, from old view, which held that the sovereign ruler had the right to govern his own territory; to the modern view, which generally holds that people have the sovereign right to self-determination.
\end{abstract}

\section{Keywords}

Namibia, Decolonization, Self-Determination, United Nations, Sovereignty

\section{Introduction}

For nearly three-hundred years, the idea of Westphalian Sovereignty held that the individual states, governed by sovereign rulers, had certain rights to be respected even by adversaries. However, beginning quite rapidly at the midpoint of the Twentieth Century, these long-held ideas of sovereignty began to change, shifting the power from governors who had sovereign rights to territory and determination to individuals who collectively held the power to choose their own destiny (Reisman, 1990). After WWI, all colonial powers voluntarily ceded their colonies, except for South Africa, which con- 
tinued to subject the Namibian People to their apartheid rule. However, in 1960, the United Nations issued an official declaration, Declaration $1514 \mathrm{XV}$, which granted indigenous peoples' "the right to self-determination; by virtue of that right they freely determine their political status". This declaration, and its subsequent application to the situation in Namibia, seemed to disregard South Africa's sovereign right to rule their own people, and instead recognized the native populations' sovereign right to self-determine their own political status.

\section{Early Ideas of Sovereignty: The Westphalian Model (Western World, 1648-1948)}

While in our modern definition of sovereignty, we may naturally consider the rights of individuals as sovereign; however, this was not always the case. Treaty of Westphalia (1648) establishes, among other things, the fundamental tenants of a sovereign nation, not a sovereign people. According to Bring (2000), Westphalian Treaties "provided the ideological justification for ultimate control within a specific territory at the same time that it provided a basis for recognition from other state". These Westphalian ideas influenced many facets of society and of international relations. The UN was, in many ways, based on the unification of Westphalian ideas with the idealism that defined the League of Nations.

The idea of "individual sovereignty" is not new, and it has its root in Hobbes and the Social Contract, Mathie (1988) but was never intricately applied to international law. Clearly, until very recently, sovereignty was not applied to individuals on an international scale, but rather to individual governors. This, however, changed halfway through the 20th century (Reisman, 1990).

\section{History of Namibia and Colonization (Africa, 1884-Present)}

To better understand the transition in the conception of sovereignty, the historical context of Namibia must be examined. Namibia (South-West Africa) is a resource rich area, with diverse indigenous populations, comes under Imperial German rule in 1884. The Nama, Herero, and Damara peoples represented major groups in the territory. The colonial rule applied high taxation and forced land sales. In 1904, the Herero leaders attacked and killed about 100 Germans. The German government responded to the revolt with a genocide, killing between 24,000 and 100,000 in the Herero population. They also targeted and killed about 10,000 of the Nama ethnicity (Cooper, 2007). In 1919, the Treaty of Versailles forced Germany to give up its colonies. League of Nations gives 'mandate' to South Africa for South-West Africa and South African Colonization and apartheid is instated. However, South Africa treated the territory as its "Fifth Province" (Caporaso, 2000). Consequently, Namibian War of Independence out broke in 1966-1990. Guerilla warfare between the South African and the South West Africa People's Organisation (SWAPO), a legitimate government of Namibia under the United Nations, dominated the war. The war came to a close in 1988, when South Africa finally agreed to Namibian Independence in the New York Accords. Freeman (1989) A Namibian national identity is created throughout the long war. 


\section{History of the UN and Decolonization} (The United Nations, 1919-1948)

Essentially, the United Nations' policies played a fundamental role in the transition of perspectives of sovereignty, as well as in gaining Namibia's independence.

\subsection{The League of Nations and Mandates on the Administration of Colonies and Territories}

Extract from mandate Article 22: "There are territories, such as South-West Africa and certain of the South Pacific Islands, which, owing to the sparseness of their population, or their small size, or their remoteness from the centres of civilisation, or their geographical contiguity to the territory of the Mandatory, and other circumstances, can be best administered under the laws of the Mandatory as integral portions of its territory, subject to the safeguards above mentioned in the interests of the indigenous population". Extract analysis: this mandate specifically mentioned the laws of South-West Africa, which was classified as territories, about defending interests of the indigenous population.

Exact from mandate Article 22: "To those colonies and territories which as a consequence of the late war have ceased to be under the sovereignty of the States which formerly governed them and which are inhabited by peoples not yet able to stand by themselves under the strenuous conditions of the modern world, there should be applied the principle that the well-being and development of such peoples form a sacred trust of civilisation and that securities for the performance of this trust should be embodied in this Covenant".

\subsection{The League Essentially Gave the Colonies of Loosing States to the Victorious States of World War I as Reparations}

The League of Nations insisted on the administration of territories based on legal terms. Therefore, the mandate was established after the following two processes: The removal of previous government power which had absolute control over the territory; The transfer of mandatory powers to individual states among the Allied Powers.

\subsection{The UN Did Administer "Trust Territories" at the End of World War II and It Took a Stance against Colonialism, Hoping to Lead the Territories to Independence}

The aim of establishing a list of "trust territories" is to ensure that governments could take appropriate steps towards achieving goals from the United Nations Charter ${ }^{1}$, i.e. independence.

\section{The Significance of Universal Declaration on Human Rights and Declaration 1514 (The UN, 1948-1960)}

The transition in the conception of sovereignty is evidenced by the change of the UN Charter's declaration. The UN Charter's Declaration on the Granting of Independence

\footnotetext{
1“The United Nations and Decolonization-Trusteeship Council”. Un.org. N.p., 2016. Web. 14 July 2016.
} 
to Colonial Countries and Peoples (1514) puts more emphasis on the individual than the nation, eroding traditional ideas of sovereignty.

According to Declaration 4, "All armed action or repressive measures of all kinds directed against dependent peoples shall cease in order to enable them to exercise peacefully and freely their right to complete independence, and the integrity of their national territory shall be respected"; Declaration 1: "The subjection of peoples to alien subjugation, domination and exploitation constitutes a denial of fundamental human rights, is contrary to the Charter of the United Nations and is an impediment to the promotion of world peace and co-operation."; Declaration 2: "All peoples have the right to selfdetermination; by virtue of that right they freely determine their political status and freely pursue their economic, social and cultural development".

The UN Declaration on Human Rights helps transition sovereignty from governors to the people, evidenced by Declaration 2: "Everyone is entitled to all the rights and freedoms set forth in this Declaration, without distinction of any kind, such as race, colour, sex, language, religion, political or other opinion, national or social origin, property, birth or other status. Furthermore, no distinction shall be made on the basis of the political, jurisdictional or international status of the country or territory to which a person belongs, whether it be independent, trust, non-self-governing or under any other limitation of sovereignty" (Avalon Project, 2016). Clearly, the UN now believes that a person's fundamental human rights (their human sovereignty) can override national sovereignty.

\section{Namibia: What the UN Did (1968-1986)}

This fundamental change in the way that the international community views sovereignty is evidenced by the application of former declarations to the Colony of South West Africa. In 1968, the General Assembly passed measure 2145, which addressed Namibia and explicitly applied The UNDHR to Namibia: "Reaffirms that the provisions of General Assembly resolution 1514 (XV) are fully applicable to the people of the Mandated Territory of South West Africa and that, therefore, the people of South West Africa have the inalienable right to self-determination" In other words, the UN is recognizing that now the Namibian people have the right to self-determination regardless of South Africa's territorial claims (Likuwa, 2013). In addition, Security Council also passes Resolution 276, which reaffirms what the General Assembly has said, but gives it some "teeth" and "credibility".

According to Wallerstein (1975), both of the resolutions say basically the same thing, and the effect is that the people of Namibia (South West Africa) have rights under both UN Declaration 1514 and the League of Nations Colonial Mandate to rule. Nevertheless, South Africa has violated these rights by occupying the territory of South West Africa and imposing a system of white-oppression and apartheid (Carroll, 2015). Therefore, South Africa's occupation is illegal and illegitimate, and the people of Namibia have the freedom to rule themselves. Finally, all UN member states should refuse to recognize South African ownership of Namibia in their diplomatic relations and their 
trade pacts. The Resolution 276 was not vetoed by any permanent members and represents an almost universal agreement about this important issue of sovereignty.

Again, the fact that The UNDHR and Declaration 1514 were applied to the Namibian context represented a new-era in understanding of national sovereignty. Now, the UN clearly reaffirms that the rights of individuals are sovereign, and can override the traditional national sovereignty of a state (Reisman, 1990), in this case South Africa.

\section{Court Cases and the Transition in Ideas of Sovereignty (1966-1970)}

This new definition of sovereignty is not without its legal challenges, in fact, by viewing the International Court of Justice (ICJ) cases Ethiopia and Liberia v. South Africa and Legal Consequences for States of the Continued Presence of South Africa in Namibia, one can see the tangible transition into this new idea of sovereignty.

\subsubsection{Court Case}

In this Case, Ethiopia and Liberia sue South Africa over their apartheid policies and their colonization of South West Africa. According to the Summary of the Judgment of 18 July 1966: first, South Africa challenges the court's jurisdiction to rule in a dispute about its own territory. The court finds that it does have jurisdiction and the ability to rule. The Court does go ahead and rule on the damages, and awards South Africa the victory. They say that Ethiopia and Liberia have no business in South Africa's sovereign affairs, as they have not been "damaged" by South Africa's colonization. According the ICJ, "the Applicants had not established the legal basis of their claim", and therefore had no "legal right or interest appertaining to them in the subject- matter of the present claims".

This shows that the ICJ believes, at this time, that its role is to intermediate disputes between sovereign nations, but not to deal with the disputes of people or groups of people who believe themselves to be sovereign entities. This is the old idea of sovereignty.

\subsection{Court Case}

On the question put by the Security Council of the United Nations, "What are the legal consequences for States of the continued presence of South Africa in Namibia notwithstanding Security Council Resolution 276 (1970)", the Court published the advisory opinions. The Government of South Africa contended that the Court was not competent to deliver the opinion, because Security Council Resolution 276 (1970) was invalid for the following reasons: two permanent members of the Council abstained during the voting (Charter of the United Nations, Art. 27, para. 3); as the question related to a dispute between South Africa and other Members of the United Nations, South Africa should have been invited to participate in the discussion(Charter Art. 32) and the proviso requiring members of the Security Council which are parties to a dispute to abstain from voting should have been observed (Charter, Art. 27, para. 3). 
The Court points out that: 1) for a long period the abstention of a permanent member has consistently been interpreted as not constituting a bar to the adoption of resolutions by the Security Council; 2) the question of Namibia was placed on the agenda of the Council as a situation and the South African Government failed to draw the Council's attention to the necessity in its eyes of treating it as a dispute.

The government of South Africa subsequently advanced two more questions for not giving the advisory opinions requested, but the Court also turned it down.

The court published the advisory opinions:

1) The continued presence of South Africa in Namibia is illegal, South Africa is under obligation to withdraw its administration from Namibia immediately; 2) The member states of UN are refrained from lending any supports to South African government with reference to its occupation of Namibia.

\subsection{Difference and Significance}

In 1966, the court affirmed this "old-world" idea of Sovereignty by respecting South Africa's borders and rights to rule its people over the Namibian People's right to self sovereignty. In 1970, just four years later, the UN changed course, and ruled that South Africa's right to Westphalian sovereignty was not enough to override its human rights abuses. In the span of four years, the UN had completely changed positions on what sovereignty was, and who it protected. These two legal cases represent a change in system of belief.

\section{Counterarguments}

First, the UN often fails, even now, to distinguish between "old world" sovereignty and this new idea of personal and "group sovereignty". The UN failed to act in Kosovo, and instead insisted that Yugoslavia had sovereignty and that its hands' were tied Henkin (1999), which shows that the UN failed to recognize "personal sovereignty". The UN has failed to truly recognize a "Kurdish State", despite the effectiveness and historical precedent of the Kurdish Government, largely because of a Russian veto, which shows that the UN still fails to recognize the rights of indigenous people (Lawrence, 2000).

Therefore, the recognition of Namibia and other indigenous groups as states does not actually represent "new" sovereignty, just an extension of sovereignty to other, previously and continually marginalized groups (Evans, Genovese, Reilly, \& Wolfe, 2013). According to Evans, Genovese, Reilly, \& Wolfe (2013), “colonization and decolonization, then, can be viewed as the processes by which Westphalian sovereignty, created in Europe, was transferred to non-European states that, upon acquiring independence, were viewed as formally equal with Western states".

Secondly, Kagan-Guthrie (2011) argues that Namibia only gained independence because of the fall of the Soviet Union, and not because of anything that the UN did or didn't do. Therefore, it is irrelevant what the UN thinks, because they don't have any real influence in what is considered sovereign. 


\section{Namibia: Final Conclusions and Significance}

Namibia represented the first time that the UN and the ICJ had not only crafted resolutions to protect the right of "self determination" and "self-sovereignty", but had applied these statutes to a region in which a colonial power continued to rule and govern a colony, but where there was no "code-red" humanitarian crisis. In this way, the UN approach to Namibia represents a fundamental change in the way sovereignty is viewed.

\section{Modern Implications}

While this new view of sovereignty may have emerged in the turbulence of Namibia and the social-progressive wave of the sixties, it has many real-world impacts today.

First, the emergence, or attempted emergence, of more nations as people generally come to define "national sovereignty" as the fundamental right to self determination held by groups, is indigenous or otherwise, more groups begin to form their own nations Ellers (1996). This leads to an increase in "referendums" and nationalist movements Simpson (1996). According to (Cameron, 2011), even events like The Scottish Independence Movement can be seen to arise out of a feeling of neglect by the government and the need for self-determination of a single nation's fate.

Furthermore, creating strong, international coalitions of states becomes more difficult. Previously, as was the case with NATO, the UN, etc., a sovereign ruler simply had to agree to participate in these organizations. Now, however, because sovereignty is seen as the political self-determination of the people, a consensus must be reached by the group. Applying this to the EU, because the will of the people, often nationalistic people, now must be considered when evaluating the EU, Harmsen and Spiering (2004) argues that Euroscepticism has increased, though he does not go far enough to conclude that an intergovernmental organization like the EU is impossible. Another example is the proposed "United States of Africa", which failed to unify itself partially because authoritarian "strong-man" leaders were disposed and people in individual nations began to vote on individual leaders, who were more focused on improving the standard of living in their countries than uniting with other autocrats Nyerere (1963).

Secondly, a rise in ethnic or nationalist violence would not be surprising. As groups, even relatively small groups, begin to vie for sovereign legitimacy, violent struggle can often arise, especially when a group has several ethnic identities within. Furthermore, these armed conflicts often begin to take on legitimacy in international courts and precedents, as well as in social constructs of "morality" and "justice" Cunningham, Bakke, \& Seymour (2012) and Macklem (2006). Therefore, as more groups, and more varied groups, vie for sovereign legitimacy, the chance of conflict increases. For example, in India, democracy and self-determination empowered radical and very specific ethnic groups (Hindu nationalist sects) to mount violence against the government Kohli (1997). Increased weight is given to local identities, and friction within people of intersectional identities may increase.

As individual groups win the ability to govern themselves and the respect of the in- 
ternational community, more weight is given to individual groups.

Within this, however, it comes the internal friction between people of intersectional identities. For example, if someone is both Kurdish and Yazidi, their identity is placed under more stress as each of those groups gains recognition on the international stage, and their interests do not always align. As Elshtain (1991) argues in her book, such as Sovereignty, Identity, Sacrifice, one's identity is built on the ability of one's people to determine their status. Therefore, this intersectional identity becomes more complex as more groups gain this sovereignty.

\section{References}

Avalon Project. (2016). The Covenant of the League of Nations. Avalon.law.yale.edu. N.p., 2016. Web. 14 July 2016.

Bring, O. (2000). Westphalian Peace Tradition in International Law-From Jus ad Bellum to Jus Contra Bellum, The. International Law Studies Series. US Naval War College, 75, 57.

Cameron, E. A. (2011). The Independence of Scotland: Self-Government and the Shifting Politics of Union-By Michael Keating. Parliamentary History, 30, 286-287. http://dx.doi.org/10.1111/j.1750-0206.2011.00271_17.x

Caporaso, J. A. (2000). Continuity and Change in the Westphalian Order. International Studies Review, 2, 1-28.

Carroll, F. (2015). South West Africa and the United Nations. Lexington, US: The University Press of Kentucky.

Cooper, A. D. (2007). Reparations for the Herero Genocide: Defining the Limits of International Litigation. African Affairs, 106, 113-126. http://dx.doi.org/10.1093/afraf/adl005

Cunningham, K. G., Bakke, K. M., \& Seymour, L. J. (2012). Shirts Today, Skins Tomorrow: Dual Contests and the Effects of Fragmentation in Self-Determination Disputes. Journal of Conflict Resolution, 56, 67-93. http://dx.doi.org/10.1177/0022002711429697

Ellers, M. N. S. (1996). The New World Order: Sovereignty, Human Rights, and the Self-Determination of Peoples.

Elshtain, J. B. (1991). Sovereignty, Identity, Sacrifice. Social Research, 58, 545-564.

Evans, J. (2013). Ann Genovese, Alexander Reilly, Patrick Wolfe. Sovereignty: Frontiers of Possibility. Honolulu: University of Hawaii Press.

Freeman, C. W. (1989). The Angola/Namibia Accords. Foreign Affairs, 68, 126. http://dx.doi.org/10.2307/20044012

Harmsen, R., \& Spiering, M. (2004). Euroscepticism and the Evolution of European Political Debate. Euroscepticism, 20, 13-35. http://dx.doi.org/10.1163/9789401201087_002

Henkin, L. (1999). Kosovo and the Law of "Humanitarian Intervention". The American Journal of International Law, 93, 824-828. http://dx.doi.org/10.2307/2555346

Kagan-Guthrie, Z. (2011). Cold War in Southern Africa: White Power, Black Liberation. Journal of Cold War Studies, 13, 244-246. http://dx.doi.org/10.1162/JCWS_r_00122

Kohli, A. (1997). Can Democracies Accommodate Ethnic Nationalism? Rise and Decline of SelfDetermination Movements in India. The Journal of Asian Studies, 56, 325-344. http://dx.doi.org/10.2307/2646240

Lawrence, D. A. (2000). A Shaky De Facto Kurdistan. Middle East Report, No. 215, 24. http://dx.doi.org/10.2307/1520151 
Legal Consequences for States of the Continued Presence of South Africa in Namibia (South West Africa) Notwithstanding Security Council Resolution 276 (1970) (1970-71). (n.d.). The Development of Human Rights Law by the Judges of the International Court of Justice. http://dx.doi.org/10.5040/9781472563859.ch-016

Likuwa, K. M. (2013). Refining Conflict Resolution Theory-Liberating Namibia: The Long Diplomatic Struggle between the United Nations and South Africa. By E. Ike Udogu. Jefferson, NC: McFarland \& Co., 2012. Pp. ix+253. \$55, paperback (isbn978-0-7864-6576-7). The Journal of African History, 54, 296-297. http://dx.doi.org/10.1017/S0021853713000418

Macklem, P. (2006). Militant Democracy, Legal Pluralism, and the Paradox of Self-Determination. International Journal of Constitutional Law, 4, 488-516.

http://dx.doi.org/10.1093/icon/mol017

Mathie, W. R. (1988). The Critical Failure of Hobbes-HamptonJean: Hobbes and the Social Contract Tradition. (Cambridge: Cambridge University Press, 1986. pp. xii, 299. \$42.50.). The Review of Politics, 50, 334-336. http://dx.doi.org/10.1017/S0034670500015795

Nyerere, J. K. (1963). A United States of Africa. The Journal of Modern African Studies, 1, 1-6. http://dx.doi.org/10.1017/S0022278X00000677

Reisman, W. M. (1990). Sovereignty and Human Rights in Contemporary International Law. The American Journal of International Law, 84, 866-876. http://dx.doi.org/10.2307/2202838

Simpson, G. J. (1996). The Diffusion of Sovereignty: Self-Determination in the Post-Colonial Age. Stanford Journal of International Law, 32, 255.

Summary of the Judgment of 18 July 1966, South West Africa (Liberia v. South Africa). The United Nations, The International Court of Justice.

The United Nations and Decolonization-Trusteeship Council. Un.org. N.p., 2016. Web. 13 July 2016.

The Universal Declaration on Human Rights, United Nations. Un.org. N.p., 2016. Web. 13 July 2016.

United Nations General Assembly Resolution 2145 (XXI), Question of South West Africa.

United Nations Security Council Resolution 276, The Situation in Namibia, 30 January.

Wallerstein, I. (1975). Book Reviews: John Dugard (ed.), The South West Africa/Namibia Dispute: Documents and Scholarly Writings on the Controversy Between South Africa and the United Nations. Berkeley, University of California Press, 1973, pp. xix, 585, \$ 8.95. Journal of Asian and African Studies, 10, 242-244. http://dx.doi.org/10.1177/002190967501000327 
Submit or recommend next manuscript to SCIRP and we will provide best service for you:

Accepting pre-submission inquiries through Email, Facebook, LinkedIn, Twitter, etc. A wide selection of journals (inclusive of 9 subjects, more than 200 journals)

Providing 24-hour high-quality service

User-friendly online submission system

Fair and swift peer-review system

Efficient typesetting and proofreading procedure

Display of the result of downloads and visits, as well as the number of cited articles

Maximum dissemination of your research work

Submit your manuscript at: http://papersubmission.scirp.org/

Or contact ojps@scirp.org 